\title{
Global changes - new urban realities: University of Basel's contribution to the study of contemporary urban and regional development
}

\author{
Rita Schneider-Sliwa, Basel
}

\section{Challenges for local economic policies and the role of Human Geography}

Urban/metropolitan areas of industrialized nations are facing challenges which require new economic and urban policies and new analytical research and problem solving skills (AKADEMIE FÜR RAUMFORSCHUNG UND LANDESPLANUNG - ARL 2011). Amongst such challenges are (SCHNEIDER-SLIWA 2001: 160011, 160014):

- increasing competition between metropolitan areas due to globalization of the economy and international competition

- deregulation, separation of social politics from economic policies, leading to a decline of welfare and possible intensification of social problems

- economic and political integration, political change and crises which initiate migration flows, increase the polarization of society and affect the perceived quality of the urban environment

- change of societal values and pluralism of life styles, encouraging urban exodus and the concentration of marginal groups in the inner city.

In order to retain competitiveness and build up local (endogenous) potentials or to govern uncontrollable cities, new models, modes and mechanisms of planning have been developed in recent years. In cities of the Western world, public-private partnerships coalitions of major local economic and political players - have drawn up and implemented grand visions of development. These often went hand in hand with agreements on specific infrastructural, architectural, economic, social and land use policies that then directly influenced corporate locational decisions. Megacities of low income countries, in contrast, have yet to cope with the more basic infrastructural needs of their populations. What is evident from recent developments is that in cities worldwide, both urban planning and the prevailing urban regime, its orientation and complex interaction with the regional, national or supranational economic and political systems have a significant effect on the development of cities and regions. In order to deal with contemporary urban and regional development, decision-makers will need to rethink urban and regional processes, structures and policies (SCHNEIDER-SLIWA 2001: 160011, 160014).
How can a discipline like Human Geography make a contribution towards understanding issues and problems of urban and regional development? How can it contribute to generating knowledge contexts for action and strategic guidance? And how does Basel University's Human Geography contribute to developing the necessary competence in terms of knowledge, skills and attitude to research, engage and participate in local and regional development?

Human Geography has an important role to play in monitoring trends of urban and regional development, providing basic information for the optimization of local strengths, designing urban and regional development concepts which adequately provide for local needs and demands and supporting an urban planning which equally respects collective decisions, increased competition, modern urban structures, and individual characteristics of cities and urban subareas. Geographic social science research defines and analyzes control factors of urban and regional development and brings to light basic information about urban and regional structures and processes, as well as perceptions of cities and regions and their attractiveness. The range of urban and regional research topics includes development processes such as (SCHNEIDER-SLIWA 2001: 16008):

- problems of increasing social differentiation in urban subareas and at the lower end of the socioeconomic hierarchy

- population change (socio-demographic, socio-economic and socio-cultural), infrastructural and policy adjustments

- housing and labor market developments

- urban and regional environmental quality

- the potentials of local planning responses to urban and regional development.

A specific strength of Geography studies, and Human Geography studies in particular, lies in the emphasis

Based partly on: SCHNEIDER-SLIWA, R. (2012): Humangeographie / Stadt- und Regionalforschung an der Universität Basel. Forschung - Lehre - Kompetenzentwicklung. - In: Regio Basiliensis 53, 1-2: 27-36, and SchNeider-Sliwa, R. (2001): Urban geography - modern discipline for contemporary urbanism. - In: Smelser, N.J. \& P.B. Baltes (eds): International encyclopedia of the social \& behavioral sciences. -26 v., New York: Elsevier: 16008-16015. 


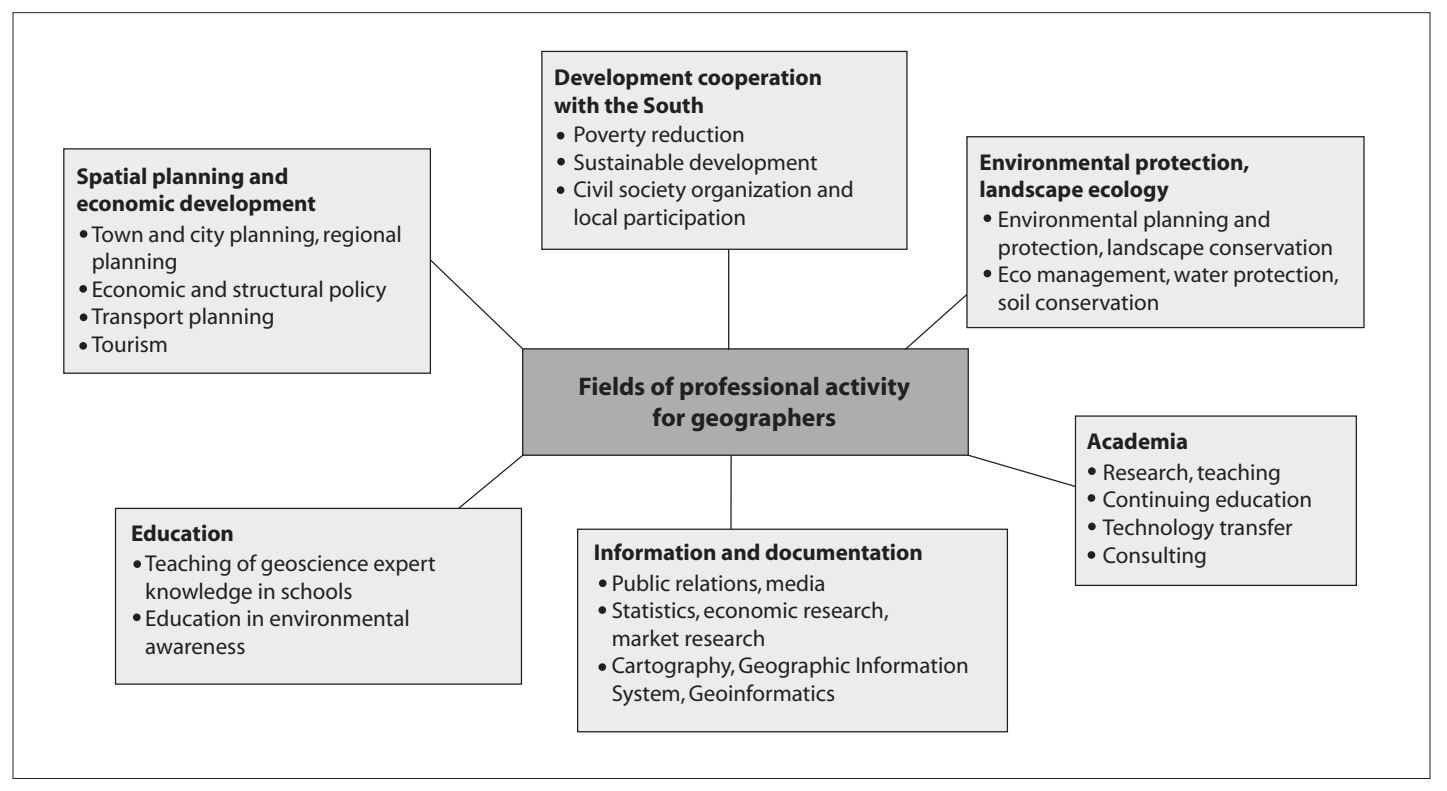

Fig. 1: Fields of professional activity for geographers Berufsfelder der Geographie

Champs d'activité professionelle des géographes

Source: own design

on developing cognitive and methodical skills, such as spatial data research and information management, as well as the abundant opportunity to use field methods of data collection or apply descriptive and analytical statistics. Geographic sciences make use of Geographical Information Systems (GIS) and spatial data analysis for the production of GIS documents to analyze and solve a wide variety of spatial problems. Geographers, especially those with a focus on urban and regional development, should be able to systematically assess the economic, social or environmental impact of public spatial policies. Consequently, they can be of assistance to decision-makers, for example, when there is a need for:

- spatial data processing, i.e. map making and analysis of data for exploring economic, social, urban and environmental issues at local, regional, national, and global scales, in particular the analysis of public and commercial base data where the spatial dimension is of pivotal importance. Such data relate to the urban and regional economy and demography, resource management, location of firms, urban and regional planning, transportation and communication, land use issues, landscape ecology and environmental quality
- a comprehensive, «integrative» perspective of urban and regional development challenges i.e. a need for social, economic and environmental indicators to be combined and interlinked

- designing or selecting policies or programs based on assessments of needs

- devising urban and regional revitalization strategy plans based on a «sense of place», i.e. the specific characteristics of a place given by its geography, history, political, societal and economic characteristics.

Human Geographers with a specialization in Urban and Regional Development, then, make use of the science of Geography to support decisions on whether or not to develop cities and regions in view of increasing economic opportunity, preserving the built and natural heritage, and/or creating a safe, aesthetic and sustainable environment. With this in mind, Human Geography, as understood at the University of Basel, is seen as an applied science with a competence and career-oriented education in mind. It concentrates on building up the expertise of students to contribute towards shaping either public policy in urban planning in towns, cities and rural areas, and/or corporate strategies with a spatial dimension, and in general, towards helping society as a whole achieve sustainability, equi- 


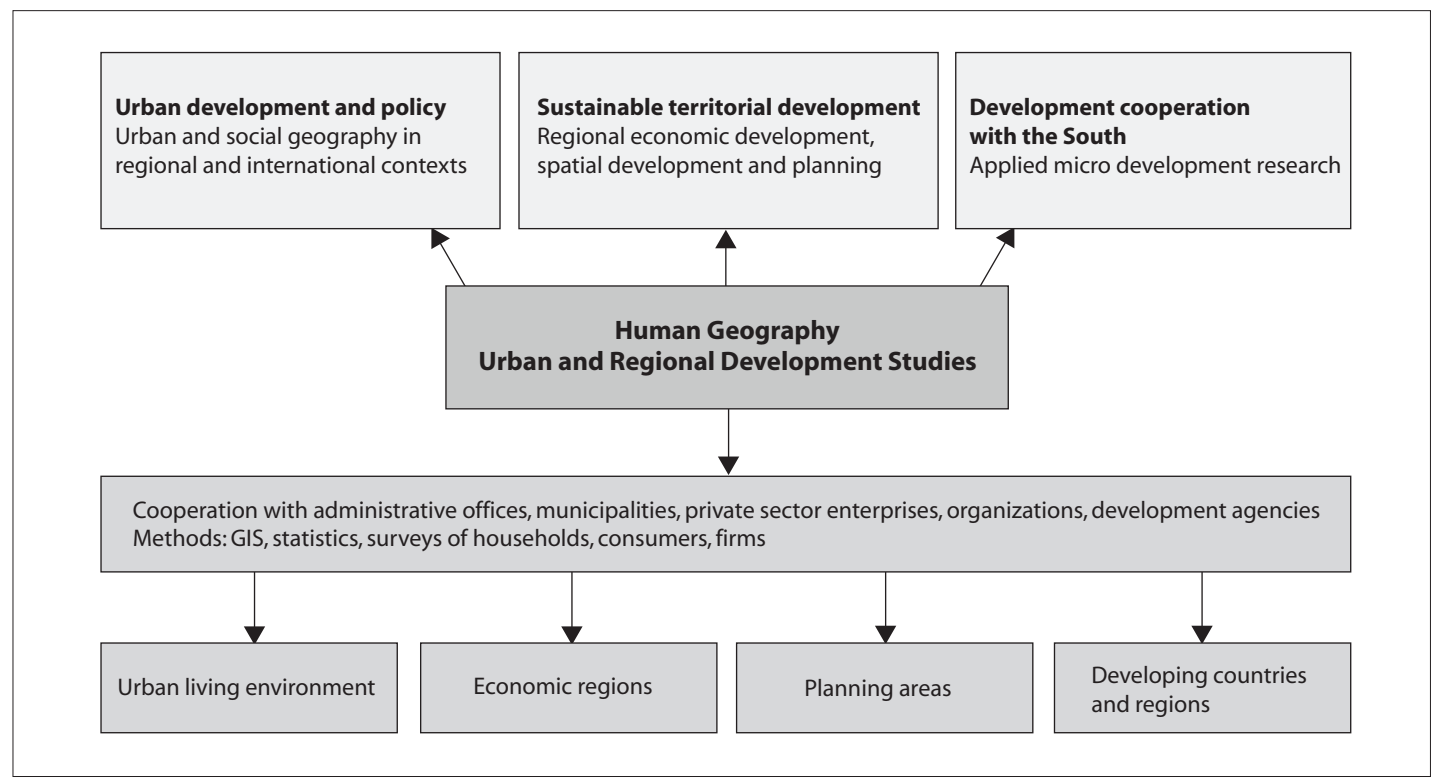

Fig. 2: Research and teaching foci of Human Geography / Urban and Regional Development Studies at the University of Basel

Schwerpunkte der Basler Humangeographie / Stadt- und Regionalforschung

Champs de recherche et d'enseignement en géographie humaine et études urbaines et du développement régional à l'Université de Bâle

Source: http://humgeo.unibas.ch/research/emphasis/

tability and a high quality of life. The key qualifications of geographers prepare them for professional activity in a variety of fields, such as public administration, economic development and promotion agencies, consulting, private sector enterprise, associations, foundations and non-governmental organizations, including the educational sector (see SANDNER \& Wiessner 1996) (Fig. 1).

\section{Approaches to the study of urban and regional development at Basel University}

Human Geography at Basel analyzes questions related to urban and regional development using social and regional science, statistical and GIS-assisted methods. We train experts for local government, social service organizations and businesses on issues related to spatial development, especially in areas of urban and regional development, spatial data analysis and household, consumer and business survey analysis. We therefore work closely together with end users in public administration, the private sector, agencies of urban, regional and economic development and non- governmental organizations. With the regional context of the University of Basel in mind, our research and teaching focuses on four areas of need within the Swiss and regional labor market. Our emphasis therefore is on basic and applied research in the following fields of activity (Fig. 2):

- Urban development and policy - urban and social geography in regional and international contexts

- Sustainable territorial development - regional economic development, spatial development and planning

- Development cooperation with the South - applied micro development research.

Within each field of activity, we focus on selected issues in which we provide research opportunities, collaboration with experts in the field and practical training.

\subsection{Urban development and policy}

Urban and social geography. Urban and metropolitan areas are centers of economic growth, research and development, cultural and social change. Cities are the microcosm of society and they reflect general societal 
and social structures, trends and conflicts. he structure, distribution and dynamic of the urban population have an impact on the economic strength of the city and its capacity to finance central urban functions of public administration. Also, housing and labor market developments, market potentials and private sector location decisions are dependent on developments of a city, a city region, the urban population and subpopulations. Urban areas are highly differentiated complex systems displaying social status differentiation and segregation: we study their sub-areas, the social and economic characteristics of urban neighborhoods, the social patterning of local residents by ethnicity or class, and the behavior of subpopulations as a function of their social group or class, or as mediated by the characteristics of the neighborhood or urban subarea. We work on population structure and demographic change, questions of urban development and policy with a view on building up urban areas as centers of employment and places to live, with long-term local comparative advantages.

Micro scale urban social geography studies analyze detailed socio-economic structural patterns and processes of change and the increasing differentiation of urban social milieus at the block level using Geographic Information Systems (GIS). Survey methods are used to analyze activity systems/patterns of individuals or households, as well as preferences, felt needs, perceived quality of the urban environment, locational/residential behavior or social group behavioral patterns, appraisal, group perception and evaluation of spaces. The results of urban research increasingly serve as a basis for decisions on public investment, allocation of resources, and socio-economic and urban development policy.

Regional and international focus. Human Geography in Basel examines urban development both within the global context, for example, the emerging economies of India and China, especially in the Pearl River Delta, and to a large extent within local and regional contexts, such as in Switzerland, the trinational Upper Rhine Valley region, North Western Switzerland and in the Basel Metropolitan Area. The latter regions are part of a European Megalopolis, a major urbanized area in Western Europe with a population of around 110 million. This region is not only an area of economic strength and global importance, but also one of great cultural tradition and of particular importance with respect to European transportation and traffic systems, education and language. The region is characterized by a historically developed decentral urban system of small cities in which complementarity and cooperation have long been cultivated and were instrumental in making the region the first «European cross border region». It is further characterized by a natural and cultural landscape of great value, and there are comprehensive concepts for cross border planning and the promotion and marketing of a trinational regional economy and infrastructure. With the forces and processes which characterize globalization clearly and easily identifiable within the perimeters of the Upper Rhine Valley, the region doubles as an valuable study object for globalization as well. On the one hand the area has to deal with loss of regional identity and growing social problems as a result of increased mobility and firm relocations. On the other hand, firms and the population in general can profit from differences in prices and wage structures between different locations, and from different national regulations - aspects which contribute towards making this region one of the premier growth regions in Europe. There are, of course, also major challenges resulting from precisely those differences: in terms of regulations, administration and cross border research and political relations.

Examples of local, regional and international studies. Our studies identify, describe and analyze the processes, challenges and potentials of Basel. Some have addressed the bonds between the city and its surrounding area in terms of economic links and commuting (GRIEBEL 2012; SCHNEIDER-SLIWA 2003; SCHNEIDERSLIwA et al. 2009). Other research has focused on the urban social fabric, economic structures and functions at the meso and micro scales. Here, small area analyses with a limited set of variables grounded in social theory and common socio-economic attributes of individuals were used to characterize particular phenomena of urban sub-areas or urban space (ALU 2010; Eder Sandtner 2005; Gloor 2012; SANER 2010). Specific studies have addressed, amongst others, social welfare - socioeconomic structure and spatial distribution of welfare recipients (SANER 2010); crime rates in Basel - spatial structure of delinquencies, location of crime and residences of delinquents (ALU 2010), spatial distribution of the rent index in the housing market and quality of residential locations (EISENRING 2008); housing market, vacancy, new development, conversion (Hеммі 2008); social and neighborhood change (AMMANN 2004; Booz 2009), housing needs of the elderly (SCHNEIDER-SLIWA 2004) or young adults (Schneider-Sliwa, Erismann \& Börner 2005). Of note are the thematic analyses in response to various issues of cantonal, urban and communal agencies involving large scale social science surveys of households, consumers and firms. Among such studies are those that analyze the attractiveness of Basel in terms of a place of residence and work, as location for firms and destination for tourists (SCHNEIDER-SLIWA et al. 2009). Further, studies have been completed on the perception of city quarters or how museums may be seen as an economic driver. Within the context of teaching urban social geography and urban subarea 
development we focus on theoretical and methodical basics for the analysis, representation, interpretation and evaluation of structures and processes of urban space, city quarters and socio-demographic and urban development as well as policy and market induced changes in spatial and settlement development.

In an international context, research emphasis is also given to the connection between policy, planning and socioeconomic structures and processes at the local, metropolitan and regional scales. Such studies may be situated in selected urban/metropolitan contexts which pursue innovative planning approaches, such as the green planning of Curritiba, Brasil (EpP 2009), in capital cities that have experienced political changes (for example Hong Kong, Berlin, Jerusalem, Moscow) (Breitung 2001; SchneIder-Sliwa 2005), or in the Pearl River Delta, China.

Focus on urbanization and metropolitan area planning in the Pearl River Delta of China. China is experiencing rapid economic growth with concomitant societal, regional and political changes. Such changes open up many opportunities for foreign industrial investment, but also lead to widening developmental disparities within China's urban industrial and rural areas. In 2007 the Basel University's Department of Geography/Urban and Regional Studies and the Department of Urban and Regional Planning of Guangzhou's Sun Yat-Sen University began cooperating at the level of field trips and field research. This led to regular visits from both sides to the Pearl River Delta and Switzerland, respectively. Our studies in the area focused on urbanization, commercial development and industrial development at three different scales: the micro, the meso and the macroscale. At the micro-scale the emphasis was on urban village research (ZANOLA 2010). Urban villages in this context are defined as areas of poverty within modernized Chinese cities. Here, local communities live at poverty levels with less than standard infrastructure (in comparison to the rest of the city). Local self-help mitigate the deficits stemming from state or local government policies. ZANOLA's research looked at life in an urban village and the role of self-help organizations against the background of urban encroachment and the threat of forced removals. ZANOLA argues that social self-organization and self-help strategies based on social relations among the residents of urbanized villages are one of many assets of the village. These assets should be analyzed and integrated in some way into redevelopment plans, thereby helping to preserve assets that would support a more sustainable development. It appears that so far social aspects have been neglected in planning in the area, an aspect which is unexpected, given the high status given to social ties in Chinese culture (Fig. 3).

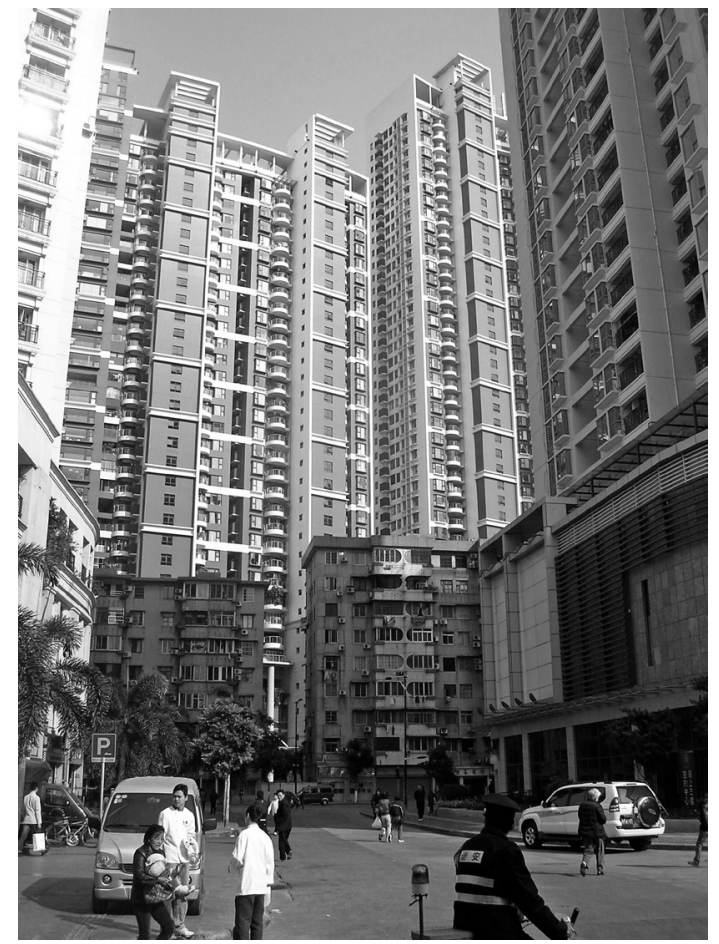

Fig. 3: Architectural contrasts and social disparities in urban China: Xiadu Urban Village in Guangzhou (in the foreground), modern urban riverside development (in the background)

Städtebauliche und soziale Gegensätze im Stadtbild: Xiadu «Urban Village» inmitten von Guangzhou (im Vordergrund), moderne Wohnanlage in Hochbauweise an der Uferpromenade (im Hintergrund)

Contrastes architecturaux et disparités sociales: «village urbain» de Xiadu à Guangzhou (premier plan) et développement urbain en bordure de fleuve (arrièreplan)

Photo: C. SaAlfrank 2009

At the meso-scale, research targeted CBD planning within one urban district: Guangzhou's Haizhu District. BRENCIC (2010) explores the massive spatial planning of selected districts where modern, Manhattanized downtowns are rapidly being stamped out of the ground. The research focus was on the role of cross-cultural learning and international experience in the planning and making of global Alpha-cities. At the macro-scale of metropolitan area development, Probst (2010) analyzed the Master planning for the development of the first «global twin city» ShenzhenHong Kong. The aim was to document the large scale 
merger and to explore the cooperation between the involved agencies in Hong Kong and Shenzhen.

Common with all of these research projects is the desire to make research purposeful. Starting off with an analysis of the changing configuration of the city and the identification of processes by which metropolitan areas grow and expand beyond their rigid corporate limits, the projects moved on to identify urban and regional policy that can contribute towards improving regional comparative advantages and competitiveness, effectively marketing the city and metropolitan region and addressing both social cohesion and the environment.

\subsection{Sustainable territorial development - regional economic development, spatial development and planning}

\subsubsection{Regional economic development}

In this field of activity, patterns and processes of regional growth under conditions of global competition are examined. The objective is to understand the development and functioning of competitive regions and to identify the determinants of competitiveness and the functioning and making of competitive regions (e.g. The Greater Basel Area, the Upper Rhine Valley, Switzerland, or selected growth areas in Asia).

Among the determinants are the innovative capacity of a region and its attractiveness for knowledge intensive firms, the engineering of competitiveness through identity and image, and the marketing of cities and regions, spatial and regional planning and, in the context of developing countries, development policy (see also 2.3 below). The competency acquired by students specializing in this area qualifies them for academic or professional careers in public administration (business promotion activity, spatial planning, statistical and information services), in private enterprises (market and market area analyses), and in non-governmental organizations (endogenous potentials and local capacity building). Most research projects have a practical orientation and are carried out in cooperation with potential end-users; hence, the studies provide a direct link to the labor market. The leitmotif of studies in this field of activity is that globalization or global crisis do not predetermine the outcome of development processes for every city or region and their political institutions. Precisely because of local differences and developments, complex urban systems as such are not likely to experience identical trends and development patterns. The way global processes manifest themselves at the local level depends strongly on the forces and processes in operation or initiated to deal with global challenges (see also Cox 1997 and Swyngedouw 1997). Local forces and pro- cesses continue to regulate and determine urban and regional development and make urban and regional development patterns as much the result of conscious local policies and priority settings as the product of the forces of globalization, global crisis, or other large scale processes. Hence, the focus is on the identification of policies that contribute towards developing local strengths, security and stability; cities and regions themselves are seen as the agents (of authority) and in control of the decision-making process (see also Cox \& MaIr 1989, 1991; Leo 1991; Logan \& Molotch 1987; VAN Vliet 2002).

Examples of regional and international studies. The EU-ESPON project SURE (HAISCH et al. 2011) is an example of a regional study. Financed by the EUESPON-Program on Targeted Analyses, it focused on the specific challenges of development of convergence regions within the European Union. Despite the fact that these regions were awarded with extensive funds to improve their socio-economic performance and competitiveness, not all regions profited to the same extent. This project explored the reasons behind the difficulty of some convergence regions to achieve the goals set. It was assumed that a clearer understanding of why some of these regions continue to lag behind would be of key importance for the success of EU cohesion policy. The focus was on identifying factors that affect above average and below average growth rates and that might relate to effective fund management and an effective public administration. It served to support regional policy-makers in their understanding of how to improve the lagging economic performance in their regions. The project systematically analyzed and compared relevant factors for economic growth in convergence regions with both high and low growth rates by focusing on economic drivers and economic enablers, which are of relevance for all European regions, as well as on factors relevant for an efficient allocation of resources (like EU funds). In view of the current European economic crisis and the rapidly declining economy of entire countries in the Union, these questions seem all the more relevant for society today.

Regional structural change and the restructuring of the regional economy were explored by STRASSMANN (2000). Particular attention has since been given to the regional economic impact of the University of Basel and the University of Applied Sciences and Arts Northwestern Switzerland (FHNW) (HAISch \& SchNeIDER-SLIWA 2007), the clustering of innovative and knowledge intensive firms in the trinational «BioValley» region of Basel, especially of firms working in gene technology, bio- and nanotechnology (KLÖPPER 2009), and of the regional economic impact of Basel University's graduates (WIELAND 2008). 


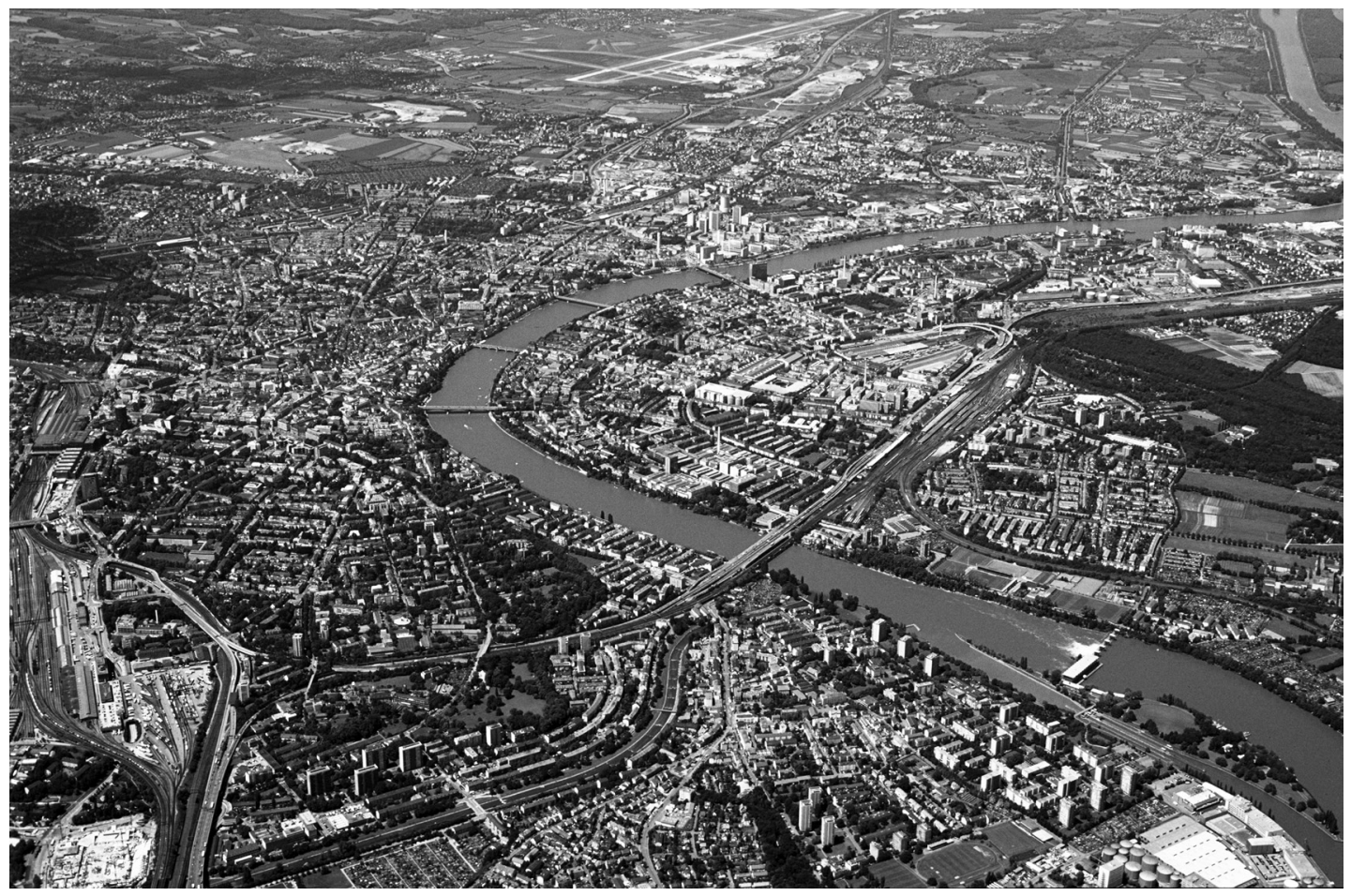

Fig. 4: Many studies at the University of Basel focus on regional economic and spatial development in the trinational border region of Basel, Switzerland

Studienfokus auf regionaler Wirtschaftsentwicklung und Raumplanung im trinationalen Grenzraum Basel De nombreuses études ont porté sur le développement économique et spatial de la région trinationale de Bâle Photo: SchweIzer LufTwAFFE (reprinted with permission)

\subsubsection{Spatial development planning as a process and agenda for economic development}

In this field of activity we work closely with town and spatial planning agencies that seek to anticipate and bring about long-term change by agreeing on strategic and flexible development paths that allow for a more sustainable and equitable future, for new investment and increased competitiveness of the region. Research projects and Master's theses target the development and analysis of relevant policy instruments and certain aspects of planning, such as the management of different types of land use, recycling of space/brownfield developments, land use reserves in built up areas, interim land use and its importance for urban quarters, the conversion and development of train stations, evaluations of successful conversions and the planning of green space (BERGER 2011; BÜCHEL 2012; MEINICKE 2011). These studies contribute to issues of local and regional spatial development especially in the preparatory phase of policy decisions. They help to fine tune and substantiate areal planning and planning projects. In many cases our students successfully complete professional practical training within these agencies, and acquire knowledge and skills that allow them to find an attractive place of employment after graduation.

Examples of recent projects are: Development of an indicator-based approach to measuring sustainable spatial development in the Canton of Basel-Land (THum 2005), settlement density and built up of town centers (FREI 2009), scenarios for the development of agriculture and forestry in the Belchen-Passwang area (WILLINER 2010), assessment of building reserves in already built-up area (WIDLER 2010), use of urban open space as cultural landscapes in the Trinational Eurodistrict of Basel (TEB) (BLÄTtLER 2011), developing an instrument for monitoring sustainable development as a result of neighborhood rehabilitation (BüCHEL 2012), and recreation in landscape development planning in the Trinational Agglomeration of Basel (TAB) (SANDTNER 2003; Fig. 4). 


\subsection{Development cooperation with the South - applied micro development research}

Concerning development issues, we work closely with selected civil society organizations and national partners on matters of applied micro-economic research of local relevance and impact. The emphasis is on informing public policy in low income countries. Following the Harvard applied micro development approach, our research in this area is characterized by the gathering of detailed micro-level data, fieldbased research that includes local partnerships, comprehensive project design, and context based analyses that assist actual policy making on the ground. For example, the research done on service delivery within the context of community development (see JoERges et al. 1966 and JoERges 1969) explored different angles of the same topic: identification of factors to increase the effectiveness of delivery of public goods and services to the poor (i.e. credit services/ microfinance, education, etc.), formulation of strategies for helping people in poverty to improve their situation, and identification of self-help strategies of people in poverty.

\section{Focus on service delivery in the educational sector.} Regarding service delivery, our primary concern is whether or not and to what extent disadvantaged groups face unequal access to goods or services on the basis of ethnic background, caste, social status, gender or institutional discrimination (FRICKER 2011; GLOOR 2011; VöLKSEN 2011). One aspect of service delivery is education: research by FRICKER, GLOOR and VöLKSEN in cooperation with Matrusmruti Trust/Swapath Trust of Ahmedabad, India addressed the reasons why despite high school enrollment rates in urban slums and rural communities of India there may be low attendance and completion rates, as well as high incidences of school drop-outs. The project addressed specifically the reasons why children drop out of schools. The survey targeted two groups of school attending children and school drop outs in urban slum communities in the City of Ahmedabad and in rural communities of Gujarat. Two main determinants were examined: the sociocultural milieu factors which are represented by household characteristics (such as caste, personal assets or educational levels of the household) and the immediate environment of a child, and institutional factors dealing with teachers' performance, the school setting and the children's perceptions thereof. This study shows that especially first generation learners struggle to complete the full cycle of primary schooling because of sociocultural milieu factors which are represented by the household characteristics, but more importantly, also by institutional parameters like teacher's absenteeism or discrimination that reproduce social inequalities through the educational system (Fig. 5).

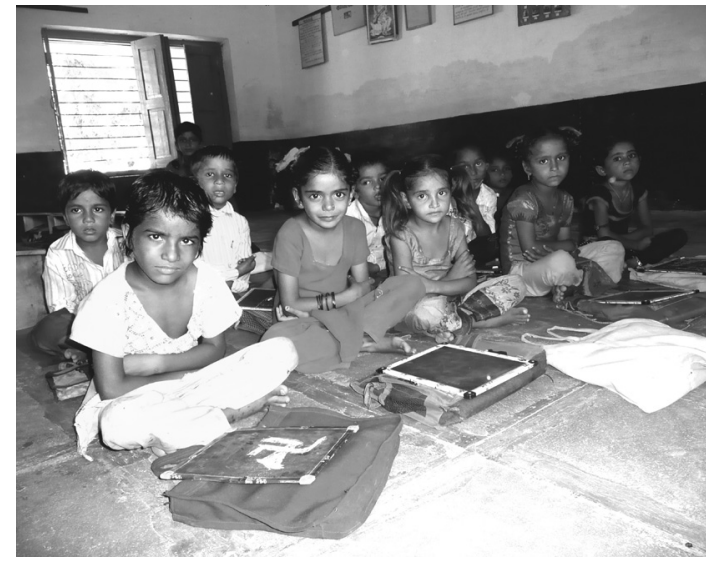

Fig. 5: Using education as a tool to rehabilitate poor and vulnerable children: public primary school in rural India, Anandpura, Gujarat/India

Grundschulbildung als Instrument der Eingliederung benachteiligter Kinder im ländlichen Indien, Anandpura, Gujarat

L'éducation comme moyen de réhabilitation pour les enfants pauvres et vulnérables: école primaire publique en Inde rurale, Anandpura, Gujarat

Photo: E. Gloor 2010

Focus on service delivery in the microfinance sector. Other aspects of service delivery were addressed by the study of micro insurance. SAALFRANK (2012) examined the partner-agent model used to deliver micro insurance. Within the partner-agent model, insurers (the partner) work together with an organization or institution (the agent or facilitator) that has an existing interface with the low-income market to reach (potential) policy holders. It is generally assumed that micro insurance schemes work well and contribute to risk mitigation and poverty reduction by transferring risk onto third parties. However, how well this functions depends to a large extent on the knowledge of insured persons on how to use the system, as well as how insurance payments are being invested and how the intermediary agency then handles the claim procedures and settlements. Using the micro insurance system facilitated by All India Disaster Mitigation Institute of Ahmedabad, India, and employing survey methods to reach micro insured who had made claims, SAALFRANK showed that there are severe deficiencies in the partner - agent model, causing long delays in the operative management (procedures and reimbursement) handled by the intermediary facilitating agency. This leads to policy holders highly indebting themselves to survive while waiting for their settlements. These 


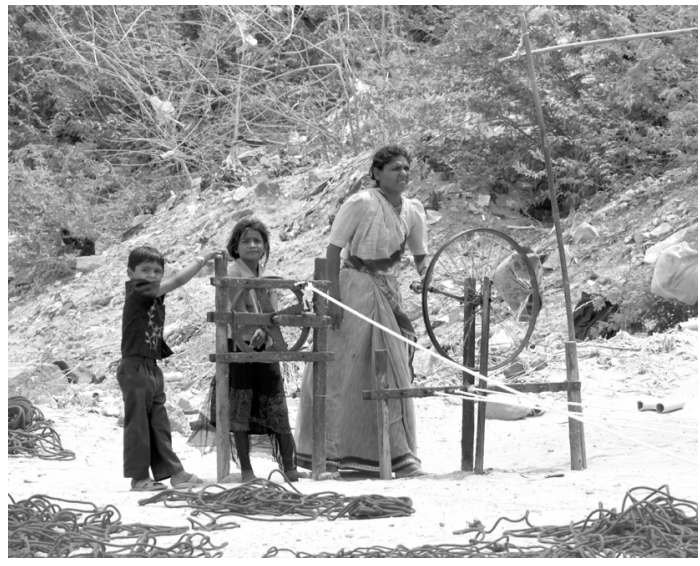

Fig. 6: Micro enterprises in the informal sector: rope production, Bhuj, Gujarat/India

Mikrounternehmen im informellen Sektor: Produktion von Sisaltauen, Bhuj, Gujarat/Indien

Micro-entreprises du secteur informel: production de cordes, Bhuj, Gujarat (Inde)

Photo: E. GLOOR 2008

policy holders are finally forced to use the insurance funds not for replacing losses but for repaying immediate debt burdens. Insured households, in such situations, may not be better off in the event of damage than uninsured households, due to inefficient delivery channels, both governmental and non-governmental.

\section{Focus on poverty mitigation and own adaptive} capacities. Regarding how people move out of poverty we focused on differentiation within poverty situations in urban slums. The project «Recovering Slums» (Schneider-Sliwa with Minir Bhatt 2008; SchneIDER-SLIWA 2009) explored the forces that account for differences in poverty structures and the more general question of how people get themselves out of poverty. Slum communities, their population and their endogenous potential, then, were at the core of this study. The focus was on local structures, forces and adaptive capacities in slum communities, how local people use their strengths and potentials for development, and on the factors that facilitate this. Rather than looking at macro milieu planning for poverty reduction, this study took a look at micro level constraints and adaptive capacities of households. Occupation and level of schooling, or savings and spending behavior, for example, emerged as more prominent determinants of differences in poverty structures than traditional caste structure. The issue of one's own adaptive capacities was also addressed by SLIwA (2011) in her study on business strategies of micro enterprises in disaster affected areas of Gujarat (Fig. 6). She examined how micro enterprises manage their businesses, handle credit, savings and investment, how they overcome and adapt to disasters/external shocks, what factors define success or failure of micro enterprises and whether or not membership in a small business association might be one such factor of success. This study showed that business and investment strategies, as well as the handling of finances, differ between the sexes: females tend to have a greater degree of financial literacy independent of formal education. In rural areas the handling of finances was marked by male behavioral patterns characterized by a more statusoriented handling of money than seen among females. Thus, it is possible that the greater financial and economic vulnerability of micro enterprises in rural areas studied may at least partially be rooted in gender-discrimination. Yet, both in rural and urban areas, being a member of a small scale entrepreneur's chamber of commerce was to some extent helpful in solving certain business problems. The personal capacity to run a successful business was also addressed by RAMSEIER (2012) in her study on E-waste management in the informal sector of Ahmedabad.

\section{Conclusion and perspectives}

Human Geography in the Department of Environmental Sciences at Basel University offers a wide spectrum of specialization at local, regional and international scales with a broad range of follow-up job opportunities. Interdisciplinary studies, a flexible modular curriculum structure and specialization accord a high degree of marketability to our graduates. Most graduates go on to work in cantonal or even Federal offices and private sector firms where spatial data analysis is important. School geography is one of the subjects required for university enrollment, and as such allows knowledge of geosciences to be transferred from university level to the school system. As part of Basel University's core areas of «Life sciences» and «Culture», Environmental Sciences is currently being developed to become a major competence center ( $«$ Center for Environmental and Life Sciences») at the interface between the two core areas. The attractiveness of the field results not only from the subject matter itself and its integrative perspectives, but also from its capacity to produce marketable graduates capable of being successfully absorbed in the labor market. As long as environmental issues continue to be of general concern for society and the need for experts on issues of man-environment relations such as represented in urban and regional development is strong, graduates in Geography and Human Geography can be assured of interesting job opportunities after their studies. 


\section{References}

Alu, R. (2010): Räumliche Strukturmuster städtischer Kriminalität in Basel - Eine GIS-gestützte Analyse der Tatorte ausgewählter Delikte im Zeitraum der Jahre 2005 bis 2009. - Masterarbeit, Geographisches Institut, Universität Basel.

Ammann, N. (2004): Sozialstrukturwandel und GISunterstützte Untersuchungen der Quartiere Clara, Wettstein, Rosental, Matthäus, Klybeck und Kleinhüningen. - Diplomarbeit, Geographisches Institut, Universität Basel.

AKADEMIE FÜr RAUMForschung UND LANDESPLANUNG - ARL (Hrsg.) (2011): Strategische Regionalplanung (von G. Tönnies). - In: Leibniz-Forum für Raumwissenschaften, Nachrichten der ARL 41, 2:1-6, Hannover. BERGER, M. (2011): Zwischennutzung und Stadtteilentwicklung. Untersuchung anhand eines Meinungsbildes des Erlenmatt-Areals in Basel. - Lizenziatsarbeit, Geographisches Institut, Universität Basel.

BLÄTTLER, A. (2011): Kulturlandschaftliche Inwertsetzung der Freiflächen im trinationalen Eurodistrict Basel (TEB). - Masterarbeit, Geographisches Institut, Universität Basel.

Booz, S. (2009): Sozialstrukturwandel in den Quartieren Basels. - Lizenziatsarbeit, Geographisches Institut, Universität Basel.

BReItUNG, W. (2001): Hongkong und der Integrationsprozess. Räumliche Strukturen und planerische Konzepte. - Basler Beiträge zur Geographie 48, Basel. BRENCIC, E. (2010): The modern model of urban planning in Guangzhou: the case of Guangzhou's Haizhu District. - Masterarbeit, Geographisches Institut, Universität Basel.

BüCHEL, L. (2012): Entwicklung eines Controlling- und Monitoringinstruments für die Nachhaltigkeitsbeurteilung innerhalb des Projekts «Stadtteilentwicklungskonzept Badischer Bahnhof». - Masterarbeit, Geographisches Institut, Universität Basel (in progress).

Cox, K.R. (ed.) (1997): Spaces of globalization: reasserting the power of the local. - New York: Guilford Press.

Cox, K.R. \& A.J. MAIR (1989): Urban growth machines and the politics of local economic development. - In: International Journal of Urban and Regional Research 13, 1:137-146.

Cox, K.R. \& A.J. MaIR (1991): From localised social structures to localities as agents. - In: Environment and Planning A 23, 2: 197-213.

Eder SAndtner, S. (2005): Neuartige residentielle Stadtstrukturmuster vor dem Hintergrund postmoderner Gesellschaftsentwicklungen. Eine geographische Analyse städtischer Raummuster am Beispiel von Basel. - Basler Beiträge zur Geographie 50, Basel. EISENRING, M. (2008): Der Mietspiegel von Basel. Eine GIS-gestützte Erfassung von Mietpreisen und Wohnanlagen. - Lizenziatsarbeit, Geographisches Institut, Unversität Basel.
Epp, I. (2009): Zukunftsstadt Curitiba - Modell für die Zukunft? Eine Untersuchung eines nachhaltigen Stadtplanungsmodells aus den 1960er Jahren aus heutiger Sicht. - Lizentiatsarbeit, Geographisches Institut, Universität Basel.

FrEI, M. (2009): Wohnverdichtungsanalysen zur Bestimmung des Innenstadtentwicklungspotentials. Eine GIS-gestützte Methode am Beispiel der Stadt Kreuzlingen. - Masterarbeit, Geographisches Institut, Universität Basel.

FRICKER, M. (2011): The relevance of psychosocial and pedogical factors on the phenomenon of urban school drop-out. Cases from Ahmedabad, India. - Masterarbeit, Geographisches Institut, Universität Basel.

GLOor, E. (2011): Institutional factors and school dropout in rural Gujarat, India. - Masterarbeit, Geographisches Institut, Universität Basel.

GLOOR, E. (2012): Quartiere im Umbruch: Einfluss des demographischen und sozialen Wandels auf Image und Identität von Quartieren am Beispiel Basels. Dissertation, Geographisches Institut, Universität Basel (in progress).

GRIeBEL, C. (2012): Grenzgänger in der trinationalen Region Basel - grenzüberschreitende Mobilität und transnationaler sozialer Raum. - Dissertation, Geographisches Institut, Universität Basel (in progress).

Haisch, T. \& R. Schneider-Sliwa (2007): Regionalwirtschaftliche und steuerliche Effekte der Universität Basel. - Basler Stadt- und Regionalforschung 29, Basel.

Haisch, T., Müller, U., PrimhaK, V. \& R. SchneiderSLIWA (2011): SEARCH, Structured empirical analysis for convergence regions: identifying success factors for consolidated growth. The ESPON 2013 Programme. Targeted Analysis 2013/2/4; Final Report | Version 2 24/12/2010; University of Naples Federico II. (This basic report exists only in an electronic version.)

Hемmi, I. (2008): Der Wohnungsmarkt in Basel. Leerstand, Neubau, Umwandlung. Eine GIS-gestützte Untersuchung. - Lizenziatsarbeit, Geographisches Institut, Universität Basel.

Joerges, B., PARK, S.J., Reichel, D. \& U. WolfF (1966): Community Development in Entwicklungsländern. - Literaturbericht im Auftrage des BMZ. 4 Bände. Saarbrücken: Sozialpsychologische Forschungsstelle für Entwicklungsplanung an der Universität des Saarlandes.

JoErges, B. (1969): Community Development in Entwicklungsländern. - Wissenschaftliche Schriftenreihe des Bundesministeriums für wirtschaftliche Zusammenarbeit 13, Stuttgart: Klett.

KLÖPPER, C. (2009): «Bio-Valley» - Innovative Cluster und wissensintensive Betriebe in der trinationalen Region Basel: Struktur, Dynamik, Verflechtungen unter besonderer Berücksichtigung der Betriebe der Gen-, Bio- und Nanotechnologie. - Dissertation, Geographisches Institut, Universität Basel. 
Leo, C. (1991): City politics in an era of globalization. - In: LAURIA, M. (ed.): Reconstructing urban regime theory. Regulating urban politics in a global economy, Thousand Oaks, Calif.: Sage Publications: 77-98.

Logan, J.L. \& H.L. Molotch (1987): Urban fortunes. The political economy of place. - Berkeley, Calif.: University of California Press.

MeINICKE, M. (2011): Bauen und Planen auf Bahnarealen. - Lizenziatsarbeit, Geographisches Institut, Universität Basel.

Probst, M. (2010): Urbanization for a global economy - the case of Hong Kong - Shenzhen. - Lizentiatsarbeit, Geographisches Institut, Universität Basel.

RAMSEIER, S. (2012): The urban poor and E-waste management in Ahmedabad. Socio-economic background and capacity of the E-waste workers involved in informal recycling. - Masterarbeit, Geographisches Institut, Universität Basel (in progress).

SAALFRANK, C. (2012): Micro insurance and the interface between insurers and insured households - an analysis of the Afat Vimo partner-agent model of micro insurance in Gujarat, India. - Basel Development Studies 4 (in press).

SAndner, G. \& R. Wiessner (1996): Der Weg der deutschen Geographie: Rückblick und Ausblick. Stuttgart: Franz Steiner Verlag.

SANDTNER, M. (2003): Die Erholungsfunktion in der Landschaftsentwicklungsplanung - ein vernachlässigtes Potential in Agglomerationsräumen. Das Beispiel der Trinationalen Agglomeration Basel (TAB). - Basler Beiträge zur Geographie 49, Basel.

SANER, R. (2010): Sozialhilfebezug in Basel - Verteilung und sozioökonomische Struktur der Betroffenen. Eine GIS-gestützte Untersuchung. - Masterarbeit, Geographisches Institut, Universität Basel.

SchneIDER-Sliwa, R. (2001): Urban geography modern discipline for contemporary urbanism. - In: SMelser, N.J. \& P.B. Baltes: International encyclopedia of the social \& behavioral sciences. -26 vol., New York: Elsevier: 16008-16015.

SCHNEIDER-Sliwa, R.(Hrsg.) (2003): Die Regio TriRhena und südlicher Oberrhein: ein Raum ohne Grenzen? Basler Stadt- und Regionalforschung 22, Basel.

SchNeIdER-Sliwa, R. (2004): Städtische Umwelt im Alter. Präferenzen älterer Menschen zum altersgerechten Wohnen, zur Wohnumfeld- und Quartiersgestaltung. - Basler Stadt- und Regionalforschung 26, Basel. Schneider-Sliwa, R., Erismann, C. \& O. Börner (2005): Wohnpräferenzen junger Erwachsener in Basel. - Basler Stadt- und Regionalforschung 27, Basel. SchNeIder-Sliwa, R. (ed.) (2005): Cities in transition - globalization, political change and urban development. - GeoJournal Library 83, Dordrecht.

Schneider-Sliwa, R. (ed.) with M. Bhatt (2008): Recovering slums. Determinants of poverty and upward social mobility in urban slums. - Basel Development Studies 1, Basel.
SchNeIder-Sliwa，R. (ed.) (2009): Local adaptive capacities and co-management in disaster risk reduction. Targeted analyses in local communities of Gujarat and Tamil Nadu. - Basel Development Studies 2, Basel. Schneider-Sliwa, R., Erismann, C., Saalfrank, C. mit Griebel, C., Klöpper, C., Sliwa, N. \& F. Wieland (2009): Das Image von Basel. Wohnort, Arbeitsort, Touristendestination und Unternehmensstandort. Basler Stadt- und Regionalforschung 31, Basel.

SchneIDer-Sliwa, R. (2012): Humangeographie / Stadt- und Regionalforschung an der Universität Basel. Forschung - Lehre - Kompetenzentwicklung. In: Regio Basiliensis 53, 1-2: 27-36.

SLIWA, N. (2011): Business and investment strategies of micro enterprises in disaster-affected areas of Gujarat, India. - Basel Development Studies 3, Basel.

Strassmann, R. (2000): Restrukturierung der Regionalökonomie der Nordwestschweiz vor dem Hintergrund der Globalisierung. Analysen, Strategien und Visionen für die Regionalpolitik und die Regionalentwicklung. - Basler Beiträge zur Geographie 47, Basel. Swyngedouw, E. (1997): Neither global nor local: «glocalization» and the politics of scale. - In: Cox, K.R. (ed.): Spaces of globalization: Reasserting the power of the local. - New York: Guilford Press: 137-166.

Thum, P. (2005): Indikatorengestützte Methodenentwicklung zur Erfassung nachhaltiger Raumentwicklung am Beispiel des Kantons Baselland. - Diplomarbeit, Geographisches Institut, Universität Basel.

VAN VliET, W. (2002): Cities in a globalizing world: from engines of growth to agents of change. - In: Environment and Urbanization 14,1:31-40; http://eau.sagepub.com/content/14/1/31.

VöLKSEN, S. (2011): The influence of individual household structures and assets on school drop-out - cases from urban slums in Ahmedabad, India. - Masterarbeit, Geographisches Institut, Universität Basel.

WIDLER, K. (2010): Nachhaltige Siedlungsentwicklung. Erhebung der Nutzungsreserven im weitgehend überbauten Gebiet als strategisches Instrument für ein nachhaltiges Siedlungsmanagement. - Masterarbeit, Geographisches Institut, Universität Basel.

Wieland, B. (2008): Brain Drain oder Brain Gain? Wohn- und Arbeitsorte von Absolventen der Universität Basel fünf Jahre nach dem Abschluss. Eine empirische Analyse anhand des Absolventen-Fragebogens des Bundesamtes für Statistik im Rahmen des «REFLEX»-Projekts. - Masterarbeit, Geographisches Institut, Universität Basel.

WiLliner, M. (2010): Entwicklungsszenarien der Land- und Forstwirtschaft im BLN-Gebiet 1012 Belchen-Passwang für die nächsten 10-20 Jahre. - Masterarbeit, Geographisches Institut, Universität Basel.

Zanola, P. (2010): Social organization and the importance of social relations of migrant workers in urban villages - the case of Xiadu Cun. - Masterarbeit, Geographisches Institut, Universität Basel. 


\section{Abstract: Global changes - new urban realities: University of Basel's contribution to the study of contemporary urban and regional development}

Global economic restructuring, the creation of a knowledge economy and the trend towards sustainability and social inclusion alter the course of local urban and regional development processes, institutions and policies. In shaping policy responses for building up competitive cities and regions in developed countries or for improved governance of uncontrollable cities in emerging economies and developing countries, local and regional policy-makers are embracing regionalization/city-regionalism and are changing administrative and governance structures at the national, regional, sub-regional and local levels. Such inter-related developments are challenges that demand an increased capacity for analysis, strategic planning and policymaking related to local urban and regional development. The article presents the approaches towards the study of urban and regional development characterizing Human Geography at Basel University, as well as its emphasis on professional training in these areas of specialization.

Keywords: urban and regional development, competitive regions, Human Geography at the University of Basel, urban and regional studies at Basel

\section{Zusammenfassung: Globale Herausforderungen - neue städtische Lebenswelten. Der Beitrag der Basler Geographie zu einer zeitgemässen Stadt- und Regio- nalforschung}

Globalisierung, die Entstehung der Wissensökonomie, der Einbezug von Nachhaltiger Entwicklung und sozialer Sicherheit in die Politik führen zu Veränderungen von Stadt- und Regionalentwicklungsprozessen, Institutionen und Planungspolitik. Um die Wettbewerbsfähigkeit von Städten und Regionen in Industriegesellschaften und die Regierungsfähigkeit von unkontrollierbaren Metropolen in Entwicklungsund Schwellenländern zu stärken, haben politische Entscheidungsträger Regionalisierung, Stadt-Regions-Kooperationen, Verwaltungsreformen und neue Gouvernanzformen auf allen staatlichen Ebenen einbezogen. Solche Strukturänderungen verlangen nach einer Prozessbegleitung im Bereich von Ausbildung und Forschung, um die individuellen und institutionellen Kapazitäten für Analyse, Strategie-Design und Planungspolitk für die Neue Stadt- und Regionalentwicklung zu erweitern. Dieser Beitrag zeigt auf, welchen Beitrag die Basler Humangeographie mit ihrem Fokus auf Stadt- und Regionalforschung in der Forschung und der Ausbildung von Fachpersonen für diese Bereiche leistet.

Schlüsselwörter: Stadt- und Regionalentwicklung, wettbewerbsfähige Regionen, Basler Humangeographie, Stadt- und Regionalforschung in Basel

Résumé: Changements globaux et nouvelles réalités urbaines. La contribution de l'Université de Bâle à l'étude du développement urbain et régional

La restructuration de l'économie mondiale, la création d'une économie de la connaissance et le mouvement vers la durabilité et l'intégration sociale ont un profond impact sur le développement urbain local et régional, sur les institutions et sur les politiques mises en œuvre. En élaborant des politiques permettant de renforcer la compétitivité des villes et des régions dans les économies avancées ou de mieux contrôler la croissance urbaines dans les économies émergentes ou en développement, les élites locales et régionales ont appuyé la régionalisation et le développement métropolitain et ont contribué à transformer les structures administratives et de gouvernance à tous les niveaux. Ces évolutions interdépendantes nécessitent un renforcement des capacités d'analyse et de stratégie, de manière à concevoir des politiques de développement urbain et régional qui puissent s'adresser aussi bien aux individus qu'aux institutions. Cet article présente les approches en géographie humaine qui conduisent à l'étude du développement urbain et régional et à la formation professionnelle dans ces domaines à l'Université de Bâle.

Mots-clés: développement urbain et régional, compétitivité des régions, géographie humaine à l'Université de Bâle, recherche urbaine et régionale à Bâle

Prof. Dr. Rita Schneider-Sliwa, Department of Environmental Sciences, Institute of Geography / Urban and Regional Studies, Klingelbergstrasse 27, CH-4056 Basel, Switzerland.

e-mail: rita.schneider-sliwa@unibas.ch

\section{Manuskripteingang/received/manuscrit reçu le 31.8.2011}

Annahme zum Druck/accepted for publication/accepté pour publication: 31.5 .2012 